country and to enroll themselves At Once in the great Volunteer Army which stands between us and the loss of our rights and liberties. In the coming week let every man fit for military service, who has not already done so, join the ranks, either for immediate service or as a member of the group to which he belongs, and thus justify the faith of the Nation in the Voluntary System. Make the response an overwhelming one, and victory for Britain will be assured. Promises to enlist are not sufficient. Do not delay, but become a soldier in the cause of Democracy and Liberty before December 11th.

63. Write a cheque today for National War Bonds.

\title{
HORACE GREELY LECTURES IN DUBUQUE
}

Horace Greely, the loved, hated, feared and eccentric Jew of the American press, had for some days been announced to lecture to the people of Dubuque [on March 19]. His services had been obtained at a high figure by the Literary Association of this city, and before the time appointed for the lecture to commence had arrived, the Congregational Church was crowded to its utmost capacity. * * * After the introductory remarks, which were extremely commonplace, and so chawed and mangled before they escaped from the tanbark breaking machine through which they passed, as to lose much of their force upon the audience, Mr. Greely announced for the lecture of the evening "Henry Clay." This was not a well chosen theme for a man of his acknowledged prejudices to present to a promiscuous audience called together by an association which excludes politics from its discussions.Dubuque Express and Herald, March 21, 1855. (In the Newspaper Collection of the Historical, Memorial and Art Department of Iowa.) 
Copyright of Annals of Iowa is the property of State of Iowa, by \& through the State Historical Society of Iowa and its content may not be copied or emailed to multiple sites or posted to a listserv without the copyright holder's express written permission. However, users may print, download, or email articles for individual use. 